\title{
SCIENTIFIC, CULTURAL AND EDUCATIONAL COOPERATION BETWEEN THE KINGDOM OF SERBS, CROATS AND SLOVENES AND BULGARIA IN THE 1920S
}

\author{
UDC 327(497.1:497.2)]:930.85
}

Ivan Ristić

Kruševac, Serbia

\begin{abstract}
The topic of the paper is the scientific, cultural and educational cooperation between individuals and institutions of the Kingdom of S.C.S. and Bulgaria during the first post-war decade, the role of the state (government) and political circumstances in making scientific, cultural and educational connections. We will show that there was a very pronounced correlation between political relations and relations, conditionally speaking, on the "non-political" level. "High politics" dictated the dynamics of relations in all other fields. However, linguistic and geographical closeness has made it possible to survive cultural contact, at least to a minimum, regardless of the very unfavorable political environment. The research, based on unpublished and published sources, press, and historiographic literature, represents a scientific contribution to the knowledge of mutual relations, as this topic is not researched in both domestic and Bulgarian historiography.
\end{abstract}

Key words: Kingdom of S.C.S., Bulgaria, cultural cooperation, educational cooperation, political relations.

\section{INTRODUCTION}

"As if we were separated by endless distances, so little do we know Bulgarians in the field of science, literature, art. Indeed, rare is the case, and the question is whether there is another, that two nations live one next to the other, country to country, as house to house, and wrestle in difficult battles through the centuries, they are known to each other in wars, and not further... What are the Bulgarians doing? Do they think, feel and create? Is there something in our separated life that connects us, or are we completely different? And a whole range of other questions could be asked." ("Jedan bugarski pevač u beogradskoj operi”, Politika, June 10, 1928, 6).

Received January 13, 2018 / Accepted May 25, 2018

Corresponding author: Ivan Ristić

Kruševac, Serbia

E-mail: 0807978@gmail.com 
This is the way the journalist of Belgrade's daily Politika described, poetically, but rather precisely and without overstatement, the poor state of cultural, artistic and scientific cooperation between the two countries, announcing the appearance of the Bulgarian opera singer Gospodinov in the Belgrade Opera. Rare texts in the press that, regarding Bulgaria, deal with topics outside the context of "high-level politics", speak of the fact that the public of the two countries had very little knowledge of each other, and that two nations, overloaded with negative stereotypes about the "other", and politicized and vulgarized contents about the past of mutual relations, very little is known about what they "on the other side of the border", who are geographically and linguistically close, but politically so distant, "think, feel and create."

This example sufficiently speaks about the connections to cultural, artistic, scientific and educational plans during the 1920s. They were: 1) Sporadic, i.e. unorganized (more consequence of the circumstances, rather than a plan and action); 2) Individual, i.e. more a matter of personal initiative of individuals than organizations and institutions; 3) Under the pressure of political occasions, i.e. to that extent limited that it is difficult to speak about relations in the full sense of the word, as well as about the organized and targeted activity of state and public institutions. It is more about examples of collegial solidarity and cooperation between cultural and scientific workers and institutions, somewhat more during the second half of the 1920s than the first half of the decade. Significant development of cultural-educational relations occurred only in the second half of the 1930s, after the improvement of political relations. (see Nazarska 2007, 375-384; for more details about cultural cooperation in the 1930s see archival sources: AY, 66-1271-451). ${ }^{1}$

\section{Yugoslav-Bulgarian Political RELATIONS IN THE 1920S: A BRIEF REVIEW}

Yugoslav-Bulgarian relations in the first half of the 1920s can be divided into two periods: the first, from 1919 to 1923 when the government in Bulgaria was led by the Bulgarian Agrarian National Union (BANU) headed by Aleksandar Stamboliski; and the second, since the fall of the Stamboliski's Government (1923) until the end of the 1920s. Unlike its predecessors, but also its successors, Stamboliski led a sincere reconcilable policy of "rapprochement" with the Kingdom of the Serbs, Croats and Slovenes (S.C.S.) (or Yugoslavia) and reconciliation with the Serbs, based on the Yugoslav idea, that is to say, on the platform to create a "Great Yugoslavia", which would include Bulgaria, and in which as, Stamboliski believed, would be solved all historical and actual SerbianBulgarian disputes (Ristić 2012, 1035-1038; for detailed information see: Petkov 1933). Because of the insistence of official Belgrade on the political isolation of Bulgaria, as punishment for participation and defeat in World War I, but also because of opposition, first of all, the Serbian public opinion, the policy of Stamboliski did not find acceptance in the Kingdom of the S.C.S., except in the last months of his government, with the socalled Niš Agreement (April 1923), on the mutual action of Yugoslav and Bulgarian authorities in suppressing the invasion of armed groups of the Internal Macedonian Revolutionary Organization (IMRO), whose aim was to separate a part of Macedonia

\footnotetext{
${ }^{1}$ Every archive institution has its own rules about citation of the archival documents. In our case, we cited reports and papers according rules of citation of the Archives of Yugoslavia (Belgrade) and Central State Archives (Sofia).
} 
under the Yugoslav control and unification with Bulgaria, which caused improvement of Yugoslav-Bulgarian relations (Avramovski 1968, 144-145, 179-184; Vasilev 1990; Tasić 2002). The government of Stamboliski was overthrown, and Stamboliski killed, in a coup on June 9, 1923, carried out by opponents of the regime, especially its pro-Yugoslav foreign policy: members of the secret military organization named Military Alliance, and the political organization People's Alliance, with the support of IMRO (Markov 1992, 34-50).

After the coup, the government was formed by organizers of the coup led by Professor Aleksandar Cankov. IMRO expected government assistance in intensifying the so-called "Macedonian Question". The government, however, was cautious because it had great internal problems. In September 1923, a communist uprising broke out, which was quickly suppressed. In the following period, there was an intensification of the internal conflict between the government and its opponents (Communists and BANU), in which thousands of people were killed (Spasov 2008, 138-148). In such an unfavorable situation, the Bulgarian government tried to improve its relations with the Kingdom of S.C.S., so at a conference in Sofia (October-November 1923), agreed to a series of concessions related to the realization of the Peace Treaty (Spasov 2015, 59-62). However, the main question was not solved: the attacks of the IMRO groups remained the main problem of Yugoslav-Bulgarian relations.

During 1925, the civil conflict in Bulgaria reached its peak: political killings, the terror of government over political opponents, and guerrilla and terroristic attacks as a response to repressions of the regime, were almost usual. By the end of the year, Yugoslav-Bulgarian relations had somehow settled down, but they remained tense and burdened with various crises that could easily escalate into an open conflict. At the end of 1925, there was some improvement, because the Kingdom of S.C.S. remained neutral in the Bulgarian-Greek conflict that arose in October 1925 (Ristic 2017, 325-328).

In the second half of the 1920s, relations also developed in two phases: by the autumn of 1927, political relations were relatively stable, without larger crises, except to the short-term crisis in summer of 1926, caused again by the activities of IMRO, as well as the opposition of the Kingdom of S.C.S. to granting Bulgaria a refugee loan by international financial institutions, without specifying the strict conditions for its use (see Ristić 2013). After signing an agreement of friendship between Italy and Albania in November 1926 (so-called First Treaty of Tirana), which for official Belgrade was an act of open aggression that Italy directed against the Kingdom of the S.C.S. (the Yugoslav government saw in this regard a direct Italian breakthrough to the Balkans and the beginning of the "rounding up" of the Kingdom of S.C.S. by Italy, through alliances with the unfriendly neighboring countries of the Kingdom of SHS) (see Vinaver 1985, 101-109; Burgwyn 1997, 35-46; Bjelajac 2010, 129 151), Bulgaria gained a significant place in the Yugoslav strategic plans. In this context, Yugoslav policy towards Bulgaria becomes more conciliatory and constructive, and in the Yugoslav (especially Serbian) public, which since the beginning of the 1920s was very unfriendly to the Bulgarians, more sympathetic voices could be heard from the beginning of 1927. The Belgrade press has increasingly intensified the story of "South Slav solidarity" and the need for cooperation among Bulgarians in all fields, especially in the field of "cultural approximation" (Ristić 2014, 79-87; Ristić 2017, 659-665).

The autumn of 1927 brought a new intensification of relations. IMRO, the ally and protégé of Italy, organized a series of attacks on Yugoslav territory. In one of them, in early October 1927, a senior Yugoslav officer, Division General Mihailo Kovačević, was killed in Štip. The official Belgrade response was quite sharp: the border with Bulgaria was almost completely closed; traffic was reduced to a minimum. Bulgaria found itself in a kind of 
blockade by the Kingdom of S.C.S. (Jovanović 2002, 156-157; Ristić 2014, 87-94). Such a state lasted until the beginning of 1929, when the border was reopened, and the Kingdom of S.C.S. and Bulgaria managed to agree on some measures to protect the border from the attacks of the IMRO at the so-called Pirot Conference (February 1929). (Ristić 2017, 440-470).

\section{SCIENTIFIC, LITERARY AND CULTURAL RELATIONS}

Cooperation in the field of science was primarily individual. Thus, the famous Croatian and Yugoslav historian Ferdo Šišić maintained contacts and exchanged scientific materials with his Bulgarian colleague, another well-known historian Vasil Zlatarski. In 1929, Zlatarski was elected member of the Yugoslav Academy of Science and Art in Zagreb, and in the same year he was invited by this institution and the Serbian Royal Academy to attend a gathering on the occasion of the hundredth anniversary of the birth of the Croatian historian Franjo Rački (Aleksieva et al. 1986, 26-28, 32, 35, 37-38).

An important event for intensifying cooperation among scientists, but also for affirmation of overall political relations, was the Second Congress of Byzantine studies in Belgrade (the first Congress was held in Prague) in April 1927. The Congress came at a time when Belgrade actively worked to strengthen good neighborly relations with Bulgaria, and on establishing as tough a relationship as possible. The Congress, which brought together the elite of the European Byzantine studies, was marked publicly as a cultural event of the first order. The most important newspapers noted detailed reports on its work on several pages. The delegates at the Congress were received by Yugoslavian King Aleksandar, the Prime Minister, and the Patriarch of the Serbian Orthodox Church, and the reception was attended by most of the ministers. It can be said that the Congress is interpreted as an event of national importance. Bulgarian scientists, Professor of Slavic Languages at the Sofia University Jordan Ivanov, jurist Stefan Bobčev and Byzantinologist Petar Nikov were the "biggest stars" of the Congress (see "Svečano otvaranje Vizantološkog konresa", Politika, April 12, 1927, 1-3; "Juče je u kraljevom prisustvu otvoren kongres vizantologa u Beogradu”, Vreme, April 12, 1927, 1, 3; "Vizantološki kongres pozdravlja našeg kralja", Pravda, April 12, 1927, 1-2).

A changed public image of the Bulgarians, present since the end of 1926, may be best seen in the writing of the press regarding the Byzantine studies Congress, which, in addition to scientific cooperation, had a huge role in the symbolic and propaganda plan it affirmed the new approach to Bulgaria in public. Bulgaria's delegation was welcomed very heartily. The speech of the academician Ivanov at the ceremonial opening of the congress was accompanied by "turbulent ovations" and general enthusiasm, which the press wrote about ("Ovacije bugarskom delegatu", Pravda, April 12, 1927, 2). Ivanov, otherwise a Slavist, was described as a "great Slavophile and Yugoslav", who visited Belgrade "more than ten times" (last time in 1926), and during the war, when Serbia was defeated "he had the rare courage to teach Serbian-Croatian literature at the Sofia University". To the journalist of Pravda Ivanov gave an interesting statement, which was more an echo of a political moment than a scientific statement. He said that in "Yugoslav history" there were "two great fools" - one was the Bulgarian Emperor Simeon, and the other the Serbian Emperor Dušan, because they did not unite the South Slavs, despite all the power that they possessed. In particular, the press highlighted one more detail: Ivanov, as a Slavist, mastered the Serbian language "almost perfectly", so that the king 
during reception told him that he spoke Serbian better than him ("Izjava predstavnika bugarske delegacije", Pravda, April 16, 1927, 1).

The press also presented Stefan Bobčev as a great supporter of "Yugoslavism". ${ }^{2}$ At the beginning of the interview, Bobčev noted that Bulgaria should not be attacked, because "without it, we as a whole, like the Yugoslavs (...) lose our national sense". He says that mutual errors are the cause of great evil that disabled relations between two nations, and that the past ought to be forgotten, and that culture is the best way to overcome the past ("G. Stevan Bobčev o odnosima sa Jugoslavijom", Vreme, April 13, 1927, 3). Professor Petar Nikov, at the invitation of Politika, wrote a text about the significance of the Congress, which was published on the first page in the Bulgarian language (Nikov, 1927).

In the context of Yugoslav-Bulgarian relations (but also wider), the Congress obviously successfully played its scientific-professional, but also political role, which may not have been devoted to it by the scientists themselves, but sponsors-the Royal Court and the Government. Specifying details of friendly conversations between the king and academician Ivanov, as well as the whole range of positive qualifications on account of Ivanov, Bobčev and the Bulgarian delegation in general, with a special accent on the "Yugoslavism" of the Bulgarian scientists, friendship and brotherhood with Bulgaria, the press reflected the current political tendencies.

Practically, there was no cooperation in the field of literature. As in the case of science, there were personal initiatives and relations of individual literary workers. Thus, the young literary critic Nikola Mirković, in the second half of the 1920s, maintained close relations with famous Bulgarian poet Kiril Hristov, whose poems he translated into German and wrote about them in foreign magazines. Mirković during 1926 and 1927, in the journal Letopis Matice srpske published a series of reviews on Bulgarian literature (mostly poetry), popularizing it among the Yugoslav professional literary audience (see Mirković 1926a, 38-44; Mirković 1926b, 238-242; Mirković 1927, 355-381), who, if judged by the words of one of the most famous Serbian and Yugoslav writers of that period, Veljko Petrović, almost had no idea about what was happening in Bulgarian literature - Petrović wrote that "nine out of ten Serbian writers almost do not know what is being written and who is writing there in Bulgaria" (Petrović 1927). Petrović's statement was found in the text - the answer to the text of Kiril Hristov under the title "Poetry and Understanding", published in Politika, in which the Bulgarian poet calls for cultural cooperation between Yugoslavs and Bulgarians, and overcoming hard inheritance of the past, precisely through cultural interaction (Hristov 1926). To him Petrović, as well as other cultural workers, such as Božidar Kovačević, who, in principle, supported the idea of cultural cooperation, they replied that it was not enough only to call, but to repent for any misdoings towards the Serbs. To Serbian intellectuals and writers, who constantly reminded Hristov of "the Bulgarian betrayal", words were not enough, they expected real acts (Petrović 1927; Kovačević 1926).

Not only did some cultural and scientific workers cooperate with each other, there were, however fewer, examples of cooperation among cultural institutions. During the

\footnotetext{
${ }^{2}$ Yugoslavism or the "Yugoslav idea" is an old idea which implied unity or alliance of the all South Slavs (Serbs, Croats, Slovenes and Bulgarians). One of the variations of this idea was the unification Serbs with South Slavs who lived in Austro-Hungarian Monarchy, which was achieved in 1918.
} 
1920s, there was communication between the representatives of Yugoslav theaters (in Belgrade, Zagreb, Ljubljana, Novi Sad) with the National Theater in Sofia, but that communication was more appropriate and occasional (congratulations for anniversaries, invitations to the jubilee celebrations) (Aleksieva et al. 1986, 143-146). In mid-January 1923, at the celebration of the anniversary of the National Theatre in Belgrade, the Bulgarian delegation led by director of the Bulgarian National Theater was particularly well received. Konstantin Ljudskanov-Cankov, a Bulgarian Charge d'Affaires in Belgrade, who also attended, noted that the arrival of Bulgarian artists showed that Belgrade's intellectual circles, outside of professional politics, show a special desire for Serbian-Bulgarian convergence. The director of the Belgrade Theater, the famous dramatist, Milan Grol, the diplomat referred to as a "great bugarophil". He suggested to Sofia that the artists' contacts be used to strengthen mutual connections (CSA, f. 176K, Op. 4, a.e. 2937, 1. 10-11; a.e. 2919a, 1. 9).

A few weeks later, Grol, with delegates from other Yugoslavian theaters, attended the anniversary of the National Theater in Sofia in early February 1923. In an author's article in Politika, he later pointed out impressions of the assassination attempt at Stamboliski in National Theatre (February $4^{\text {th }}$ ) during the celebration of the anniversary, when a bomb was thrown, which failed to injure the Bulgarian Prime Minister. Grol writes affirmatively on the politics of Stamboliski (Grol, 1923). A few days after the celebration of the anniversary (February $10^{\text {th }}$ ), the National Theatre in Sofia was destroyed in a fire, and the Zagreb Theatre decided to play a show whose revenue was intended for the Sofia theatre. The Ministry of Education supported this action (Aleksieva et al. 1986, 164). We would like to remind the reader that all this happened during the preparations for the Conference in Niš, where the so-called "Niš Agreement" was adopted, when YugoslavBulgarian relations were improving.

In addition to official cooperation, there was also professional-art cooperation between institutions. In August 1926, the principal of the Sofia Opera requested help from his Belgrade colleague when putting on one of Wagner's operas (Aleksieva et al. 1986, 146-147); in December of the same year the Yugoslav opera singer Kristina Rogovska-Hristić was a guest of the Sofia Opera, where she was warmly welcomed, and the guest's appointment of a member of the Sofia Opera Minkova was agreed in the Belgrade Opera ("Uspeh gđe Rogovske u Sofiji", Politika, December 31, 1926, 4); in September 1927, Yugoslav artists, headed by the famous writer from Zagreb Milan Begović, stayed in Sofia for a return visit to Bulgarian artists. The Yugoslav Ministry of Education supported these activities (Aleksieva et al. 1986, 147-148). It cannot remain unnoticed that these visits, and the intensification of cooperation in general, coincided with the improvement of the political climate in Yugoslav-Bulgarian relations (from the end of 1926 to October 1927).

\section{EDUCATIONAL COOPERATION}

Regarding educational cooperation, we did not find, for example, institutional cooperation between the ministries of education of the two countries, but there was, a certain, but not significant, cooperation between students, which could be considered an educational cooperation, since such a cooperation would be impossible without the approval of the Ministry of Education. 
When Bulgaria was hit by a big earthquake in April 1928 (see Markov 1999, 1197), in the Kingdom of S.C.S. it led to an almost general national solidarity with the Bulgarians, and a movement among the citizens to help the victims, including students. Thus, students from Kragujevac schools, animating other Šumadija schools, formed a committee to collect aid for their agemates in Bulgaria. The Student's Board collected funds, and decided to hand them over to the Bulgarian students by a delegation of Kragujevac students who, on the day of St. Cyril and Methodius, during a visit to Plovdiv and Čirpan, and who would also invite Bulgarian students whose homes were destroyed in the earthquake to spend part of their summer vacation as their guests ("Šumadijski đaci za svoje drugove Bugare", Politika, May 22, 1928, 9). The engagement of Kragujevac high school students was not simply an individual act, but it seems to be part of a wider action. Namely, in mid-July, the congress of all Yugoslav high school students adopted a resolution in which one of the aims outlined the expansion of the "idea of brotherhood and peace between our and the Bulgarian youth", for the sake of cultural and intellectual convergence, which would be the first stage in "real unity all Yugoslavs to one state" ("Rad jugoslovenske srednjoškolske omladine na kulturnom zbliženju sa bugarskom omladinom", Niški glasnik, July 15, 1928, 2).

Led by the inspector of the Ministry of Education Jovan Kangrga, Kragujevac high school students and professors, joined by the high school students from Belgrade, travelled to Sofia on May $23^{\text {rd }}$ ("Ekskurzija naših gimnazista u Plovdiv", Politika, May 23, 1928, 7). The delegation of Yugoslav students and professors was greeted solemnly and received at the highest level, as if it were a high state delegation. The journalists who followed delegation wrote that on their way to Sofia, the village children threw flowers on the train in which the Yugoslav delegation was travelling, and with ovations and exclamations greeted the Yugoslav students. A big reception was organized in Sofia. Kangrga was received by the Bulgarian Minister of Education Najdanov, and he also talked with the Bulgarian Prime Minister Andrej Ljapčev. To the President of the Bulgarian Teachers' Union he handed monetary aid from the Yugoslav Teachers' Society. In all the conversations, as well as in the professors' speeches, the importance of education in developing feelings of brotherhood and the convergence of two nations has been emphasized. Then the students visited the destroyed towns of Plovdiv and Borisovgrad, where they were also very warmly received. Kangrga handed out funds that the Yugoslav students collected (6000 dinars in Plovdiv and 3000 dinars in Borisovgrad) ("Doček naših učenika u Sofiji”, Politika, May 27, 1928, 8; "Naši gimnazisti u Plovdivu", Politika, May 29, 1928, 7; “Utisak naših djaka sa putovanja po Bugarskoj”, Politika, May 30, 1928, 9).

The problem, however, arose when the stay of students from Borisovgrad was supposed to be organized, who were invited to spend part of the vacations with Yugoslav students. The Ministry of Education had a big problem finding accommodation for only 30 Bulgarian students. The directors of the high schools in Kruševac, Jagodina, Gornji Milanovac, Užice, Belgrade (First Male High School), Čačak, Valjevo, Smederevo, Kraljevo, Pančevo and Zemun informed the ministry that they "had not received a response from the parents of their students regarding to accommodation of Bulgarian students", and as the reason most often stated was that the children of wealthy parents had gone on holiday, while the poor families could not accept hospitality. In Pančevo, Kraljevo and Jagodina, parents and students simply did not want to receive Bulgarian students (without specifying special reasons). In Smederevo they agreed to receive only three students. The Ministry of Education then asked the Ministry of Interior, the Red 
Cross and the Red Cross Organization for financial and material assistance for the accommodation of the Bulgarian students (AY, 66-1271-1520, Reports of the Principals of the Gymnasiums in Smederevo, Kraljevo, Pančevo and Jagodina to the Ministry of Educations and telegrams of the Ministry of Education to the Ministry of Interior and Red Cross Organization (May-July 1928), K. №. 615, №. 424, №. 614, K. №. 504, S. N. №. 25006 and S. N. №. 25330).

Based on the available material, we cannot give a precise answer to the question about the true motives for refusing hospitality to Bulgarian students. One of the reasons might really be the absence of a part of the students who spent their summer vacation away from their homes, but, taking a broader view of Yugoslav-Bulgarian relations, as well as the public discourse about the Bulgarians from the early 1920s, it is very possible that the rejection was a consequence of the negative attitudes toward them, despite the fact that, after the earthquake in Bulgaria, discourse of "brotherhood" prevailed in the press, calls for solidarity, humanity, good neighborhood, rapprochement, etc. It seems that it was impossible to delete what has been accumulated over the years in the public as the dominant picture of Bulgarians. In this context, it is probably not a coincidence it is actually very indicative that the, Ministry of Education tried to organize stay of Bulgarian children in the cities that were located outside the Bulgarian occupation zone during the last war (Kragujevac, Jagodina, Smederevo, etc.)

A solution for the Bulgarian students was finally found. The Red Cross, Youth Federation, Organization Adriatic Guard and Scout Society organized reception of students in their resorts in Martišnica, Stefan Grad and Cavtat. The youth of the Red Cross of Ljubljana decided to receive a large number of Bulgarian children in private accommodation. The Ministry of Foreign Affairs financially helped the accommodation of Bulgarian students ("Bugarska deca na našem primoriju", Politika, July 24, 1928, 6; "Gimnaziste iz Bugarske na našem primoriju", Politika, July 31, 1928, 8). So, the students were sent "far away" from the Serbian cities which were originally planned for their accommodation.

Secondary school cooperation that started with the visit of the Kragujevac and Belgrade High Schools continued on the pages of the secondary school magazine Đačka družina, which was pressed by approval of the Ministry of Education. According to the editor's words, the magazine received a general Yugoslav character from autumn 1928, since Bulgarian high school students were hired as associates (Damnjanović 1928, 1). In the same issue, an article in Bulgarian language of the seventh-grade students from Belgrade, Vojislav Grol (Milan Grol son-I.R.) was published in Bulgarian, titled $\mathrm{Za}$ zbliženje bugarske $i$ srpske omladine [For the rapprochement of the Bulgarian and Serbian youth] (Grol 1928, 2-3), as well as an excerpt from the letter of an eighth grade student from Sofia (who was signed with the initials St. Iv.), which began with the words: "Here's my hand extended to you, my Serbian brother, and give me yours in the name of all the Slavs!" (St. Iv. 1928a, 3).

In the next issue of the same magazine a song was published by the same Bulgarian student Moj intimni san [My Intimate Dream], which calls for unification "from Varna to Soča" and expects the day when "one nation" exclaims that there was "a lot of shedding of fraternal blood" (St. Iv. 1928b, 8). The practice of publishing the songs of Yugoslav and Bulgarian students whose topic was the Yugoslav idea, brotherhood and South Slav Unity continued in the following issues of the magazine: in one of them, in the song of a Bulgarian student (who was signed with the initials St. Hrist.) Jugoslovence [The Yugoslavian boy] (see Hrist. St. 1929, 2), a student from Kragujevac Dragan Milenković 
answered with the song Bratu Bugarinu [To my Bulgarian Brother], which starts with verse: "Crush the past, black and the sorrow..." (see Milenković 1929, 5).

On these examples it can be seen that, indirectly, through their support and approval, the educational authorities were behind the cooperation of the students, which leads us to the conclusion that this cooperation was clearly, however carefully, stimulated by the state authorities, reflecting the main trends in state policy towards Bulgaria in that period.

\section{REFERENCES}

Aleksiyeva, Afrodita Kirova, Nikolay Savov, Ginka Stamenova i Antoaneta Todorova. Bulgaro-balkanski kulturni vzaimootnoshenya 1878-1944. Sofia: Bulgarska akademiya na naukite (BAN), 1986.

Anonymous. "Uspeh gđe Rogovske u Sofiji”. Politika, December 31, 1926.

Anonymous. "Svečano otvaranje Vizantološkog konresa". Politika, April 12, 1927.

Anonymous. "Juče je u kraljevom prisustvu otvoren kongres vizantologa u Beogradu". Vreme, April 12, 1927.

Anonymous. "Ovacije bugarskom delegatu”. Pravda, April 12, 1927.

Anonymous. "G. Stevan Bobčev o odnosima sa Jugoslavijom”. Vreme, April 13, 1927.

Anonymous. "Izjava predstavnika bugarske delegacije”. Pravda, April 16, 1927.

Anonymous. "Šumadijski đaci za svoje drugove Bugare". Politika, May 22, 1928.

Anonymous. "Ekskurzija naših gimnazista u Plovdiv". Politika, May 23, 1928.

Anonymous. "Doček naših učenika u Sofiji”. Politika, May 27, 1928.

Anonymous. "Naši gimnazisti u Plovdivu". Politika, May 29, 1928.

Anonymous. "Utisak naših djaka sa putovanja po Bugarskoj”. Politika, May 30, 1928.

Anonymous. "Jedan bugarski pevač u beogradskoj operi”. Politika, June 6, 1928.

Anonymous. "Rad jugoslovenske srednjoškolske omladine na kulturnom zbliženju sa bugarskom omladinom". Niški glasnik, July 15, 1928 .

Anonymous. "Bugarska deca na našem primoriju". Politika, July 24, 1928

Anonymous. "Gimnaziste iz Bugarske na našem primoriju”. Politika, July 31, 1928.

Avramovski, Živko. "O stavu jugoslovenske vlade prema devetojunskom prevratu u Bugarskoj 1923. godine". Istorija XX veka 9 (1968): 132-86.

Burgwyn, James H. Italian Foreign Policy in the Interwar Period 1918-1940. Westport [etc.]: Praeger, 1997.

Bjelajac, Mile. Diplomatija i vojska. Srbija i Jugoslavija 1901-1999. Beograd: Media centar "Odbrana" i Akademija za diplomatiju i bezbednost, 2010.

Damnjanović, Mirko. "Svemu jugoslovenskom đaštvu”. Đačka družina 1 (1928): 1.

Grol, Milan. "Atentat na Stambolijskog”. Politika, February 9, 1923.

Grol, Vojislav. "Za sblizhenieto mezhdu balgarskite i srbski mladezhi”. Đačka družina 1 (1928): 2-3.

Hrist., St. "Jugoslovenče”. Đačka družina 4-5 (1929): 2.

Hristov, Kiril. "Pesništvo i sporazum". Politika, December 19, 1926.

Iv., St. "Odlomak iz pismoto na edin balgarski uchenik ot osmi klas". Đačka družina 1 (1928a): 3.

Iv., St. "Moya intimen s'n”. Đačka družina 2 (1928b): 8.

Jovanović, Vladan. Jugoslovenska država i Južna Srbija 1918-1929. Beograd: Institut za noviju istoriju Srbije, 2002.

Kovačević, Božidar. "Pesništvo i sporazum". Pravda, December 23, 1926.

Markov, Georgi. Parola "Sabja". Zagovorite i prevratite na Voenia sojuz 1919-1939. Sofia: Voenoizdatelski kompleks "Sv. Georgi Pobedonosec", Izdatelstvo "Nauka i izkustvo", 1992.

Markov, Georgi. "Zemetresenieto v Gornotrakiyskata nizina." In Bulgaria 20. vek. Almanah, edited by Margarit Ganev, Nikolay Nikiforov, and Petar Veličkov, 1197. Sofia: “ABV KOOP 2000" - Trud, 1999.

Milenković, Dragan M. "Bratu Bugarinu”. Đačka družina 6-7(1929): 5.

Mirković, Nikola. "Savremena bugarska lirika”. Letopis Matice srpske 1-2 (april-maj 1926a): 38-44.

Mirkovć, Nikola. "Savremena bugarska lirika”. Letopis Matice srpske 3 (mart 1926b): 238-241.

Mirković, Nikola. "Savremena bugarska lirika". Letopis Matice srpske 3 (mart 1927): 355-381.

Nazarska, Georgeta. "Bridges over the Frontier: The Cultural Contacts between the Bulgarian and the Yugoslavian Female Intellectual Elite in the Interwar Period.” Bibliotekar 3-4 (2007): 375-84

Nikov, Petar. "Vizantoloshkiya kongres i balkanskite narodi". Politika, April 17, 1927.

Petkov, Nikola. Aleksandar Stambolijski. Njegova ličnost i ideje. Beograd: Štamparija "Radenković", 1933.

Petrović, Veljko. "Pesništvo i sporazum". Politika, January 4, 1927.

Ristić, Ivan. "Politika sporazumevanja u vreme nerazumevanja. Rad Aleksandra Stambolijskog na jugoslovensko-bugarskom zbliženju (1919-1923)”. Teme 3-4 (2012): 1033-46 
Ristić, Ivan. "Između starih i novih izazova. Bugarska u politici Kraljevine SHS 1926. godine.” Tokovi istorije 2 (2013): 75-96

Ristić, Ivan. "Bugarska u jugoslovenskoj politici 1927. godine u svetlu pojačane italijanske akcije na Balkanu." Arhiv. Časopis Arhiva Jugoslavije 1-2 (2014): 79-94.

Ristić, Ivan. "Bugarska u politici Kraljevine Srba, Hrvata i Slovenaca (1919-1929)." PhD diss., Univerzitet u Beogradu, 2017

Spasov, Ljudmil. Balgaria i SSSR 1917-1944. Politiko-diplomaticheski otnosheniya.Veliko Trnovo: Faber, 2008.

Spasov, Ljudmil Jordanov. Balgarskata diplomaciya 1919-1944. Sofia: Ivrai, 2015.

Tasić, Dmitar. "Vojno-politička akcija makedonstvujuščih u Kraljevini SHS/Jugoslaviji 1919-1934." Arhiv. Ćasopis Arhiva Jugoslavije 3 (2002): 92-107.

Vasilev, Vasil At. Pravitelstvoto na BNZS, VMRO i blgaro-yugoslavskite otnosheniya. Sofia: Izdatelstvo na Balgarska akademia na naukite, 1991.

Vinaver, Vuk. Jugoslavija i Francuska između dva rata. Beograd: Institut za savremenu istoriju, 1985.

UNPUBLISHED SOURCES

AY (Archive of Yugoslavia, Belgrade) - Papers and Reports of the Ministry of Education of the Kingdom of Yugoslavia (No. 66)

CSA (Central State Archive, Sofia) - Papers and Reports of the Ministry of Foreign Affairs of the Kingdom of Bulgaria (No. 176K)

\section{NAUČNA, KULTURNA I PROSVETNA SARADNJA IZMEĐU KRALJEVINE SRBA, HRVATA I SLOVENACA I BUGARSKE 1920-IH GODINA}

Tema rada su naučne, kulturne i prosvetne veze između pojedinaca i institucija u Kraljevini SHS $i$ Bugarskoj tokom prve posleratne decenije, uloga države (vlada) i političkih prilika (političkih odnosa) u izgradnji naučnih, kulturnih i presvetnih veza. Pokazaćemo da je postojala veoma izražena korelacija između političkih odnosa i odnosa na, uslovno rečeno, "nepolitičkoj" ravni. "Visoka politika" je diktirala dinamiku odnosa na ostalim područijima. Ipak, jezička $i$ geografska bliskost učinili su da opstanu kulturni kontakti, makar na minimalnom nivou, bez obzira na nepovoljno političko okruženje. Glavna prepreka u saradnji bili su ne samo loši politički odnosi, već i dijametralno suprotna perecepcija odnosa u bliskoj i daljoj prošlosti, tačnije, međusobne optužbe za loše stanje odnosa, u čemu su prednjačile intelektualne elite. Sa poboljšanjem političkih odnosa u drugoj polovini 1920-ih godina, došlo je do intenziviranja saradnje, posebno na prosvetnom polju (između učenika i njihovih udruženja, kao i profesionalnih udruženja učitelja). Istraživanje, bazirano na neobjavljenim i objavljenim izvorima, štampi i istoriografskoj literaturi, verujemo da predstavlja naučni doprinos poznavanju međusobnih odnosa, s obzirom da je ova tema neistražena kako u domaćoj, tako i u bugarskoj istoriografiji.

Ključne reči: Kraljevina SHS, Bugarska, kulturna saradnja, prosvetna saradnja, politički odnosi. 